\title{
Editorial: Two Interesting Articles
}

\author{
Stephen Scypinski ${ }^{1}$
}

Published online: 31 August 2021

(c) The Author(s), under exclusive licence to Springer Science+Business Media, LLC, part of Springer Nature 2021

\section{Dear Readers of the Journal of Pharmaceutical Innovation:}

Since I last wrote to you in June, I had the opportunity to read two interesting and quite pertinent articles in the magazine Contract Pharma, of which I am a subscriber. The first, which appeared in the May 2021 issue, is entitled "The Word Innovation Probably Doesn't Mean What You Think It Does?" My first reaction to reading this title was honestly "Huh?" I know what innovation means. As I read further, I drew a discrete parallel to what the author was discussing with the mission of this journal: to report and advance innovative efforts and approaches in the pharmaceutical sector, be it industry, academia, or private business. The article stressed a principle I have embraced for much of my career "With challenge comes innovation" Certainly the COVID-19 situation has forced all of us to think differently and the article discussed such areas as drug supply chain, the move toward gene and cell therapy as new avenues for therapeutics, and the increased usage of contract developers and manufacturers. I came away from reading this article with a different frame of mind, not one to doubt the author but rather a "look in the mirror" at challenges I face personally but also by the readers of this journal.

The second article, which can be found in the June 2021 issue, is entitled "Waking from The Coma Of COVID-19." I have known the author of this article and understand his prerogatives. His main points state that the USA (and the pharmaceutical industry) needs to define a "new normal". Speculation abounds as to what that will look like. Over the past few months, we all understood that when we were vaccinated things as we knew then would return; however, the spread of the COVID-19 variants has shown us that is not to be, at least at this time. The article cites the ongoing challenges related to the pandemic, some of which include the inability of the US FDA to conduct facility inspections, the challenges associated with supply chain shipments, and the lack of on-site customer visits to contract manufacturers. Then, the silver lining in the cloud discusses the fact that the COVID-19 situation may well accelerate the implementation of Process Analytical Technology (PAT), thereby allowing real-time access to manufacturing data. Indeed, I am aware of several contract manufacturers that have instituted web cams and sensors allowing customers to observe manufacturing and testing from afar. Perhaps the US FDA will embrace this concept in the future. One can only speculate.

The current issue of JOPI continues to highlight articles that discuss innovative approaches to delivering active drug substances to enable bioavailability. "Off the map" approaches such as microsponges and other delivery options may be found in the current issue.

As we enjoy the waning days of summer and prepare for back to school and the office, whatever shape that takes, I want to thank all the contributors and readers who support $J O P I$ and help it thrive and grow. As I have stated, this is YOUR journal and as such fosters an open dialog with its readers and subscribers. If you have any suggestions, comments, and even criticisms, I want to hear from you. My email address is sscypinski@comcast.net. Until our next issue, stay safe and well.

Publisher's Note Springer Nature remains neutral with regard to jurisdictional claims in published maps and institutional affiliations.

Stephen Scypinski

sscypinski@comcast.net

$1 \quad$ VBI Vaccines Inc., Cambridge, MA 02140, USA 